\title{
IMPLEMENTASI PROBLEM BASED LEARNING BERKONTEKS LAHAN BASAH PADA MATERI STOIKIOMETRI
}

\section{Implementation Of Problem Based Learning Wetting Context On Stoiciometry Material}

\author{
Sri Winda ", Parham Saadi, Atiek Winarti
}

Program Studi Pendidikan Kimia FKIP Universitas Lambung Mangkurat,

Jl. Brigjend. H. Hasan Basry Banjarmasin 70123 Kalimantan Selatan Indonesia *email: sriwindawsce@gmail.com

\begin{abstract}
Abstrak. Penelitian dilakukan untuk mengetahui keterampilan proses sains dan hasil belajar peserta didik SMA Negeri 12 Banjarmasin. Problem based learning adalah model pembelajaran yang digunakan. Penelitian ini menggunakan metode quasi-eksperiment yang dilakukan dalam empat pertemuan. Variabel bebasnya adalah model pembelajaran. Teknik pengambilan sampel menggunakan purposive sampling. Teknik pengumpulan data menggunkan test dan non-test. Teknik analisis data yang digunakan adalah analisis deskriptif dan analisis inferensial. Hasil penelitian menunjukkan perbedaan yang signifikan pada keterampilan proses sains dan hasil belajar sikap peserta didik. Perbedaan hasil belajar pengetahuan yang signifikan ditunjukkan dari hasil uji-t kelas eksperimen dan kontrol. Hasil respon peserta didik kelas eksperimen menunjukkan hasil yang baik pada model pembelajaran problem based learning berbasis lahan basah.
\end{abstract}

Kata kunci: lahan basah, keterampilan proses sains dan stoikiometri

\begin{abstract}
The research was conducted to determine the science process skills and learning outcomes of students of SMA Negeri 12 Banjarmasin. Problembased learning is the learning model used. This study uses quasi-experimental methods conducted in four meetings. The independent variable is the learning model. The sampling technique uses purposive sampling. Data collection techniques using the test and non-test. The data analysis technique used is descriptive analysis and inferential analysis. The results showed a significant difference in science process skills and learning outcomes attitudes student. Significant differences in knowledge learning outcomes are shown from the results of $t$-test experimental and control classes. The results of the responses of the experimental class students showed good results on the problem based learning model wetland contextual learning.
\end{abstract}

Keywords: wetlands, science process skills and stoichiometry

\section{PENDAHULUAN}

Pendidikan merupakan kondisi dinamis yang menuntut adanya suatu perbaikan secara terus menerus. Menurut Khairunnisa, Saadi \& Leny (2017) salah satu cara untuk mengingat dan memahami konsep agar lebih mudah adalah dengan mengulang pembelajaran serta dibantu dengan media pembelajaran. Hal ini dapat memperkuat ingatan peserta didik, membangun sikap kreatif, dan rasa ingin tahu (Agusfianor, Istyadji, \& Saadi, 2017).

Model pembelajaran yang digunakan memfokuskan pengalaman belajar dikeadaan nyata berbasis masalah untuk diselesaikan peserta didik. Menurut Arends, (2008) situasi pembelajaran yang menyuguhkan persoalan nyata dan bermakna kepada peserta didik serta berhubungan dengan lingkungan peserta didik merupakan

Copyright @ JCAE-Jurnal Tugas Akhir Mahasiswa, e-ISSN 2613-9782

Program Studi Pendidikan Kimia FKIP Universitas Lambung Mangkurat 
definisi dari model pembelajaran ini. Persoalan yang nyata dalam kehidupan seharihari dapat digunakan pada pembelajaran yang menghubungkan keadaan lingkungan sekitar dengan materi pembejalaran yang akan disampaikan. Melalui pengalaman langsung, proses pembelajaran akan lebih melekat diingatan peserta didik sehingga menunjang peningkatan hasil belajar.

Hasil belajar ialah kemapuan akhir proses pembelajaran peserta didik. Hasil belajar yang memuaskan dapat didorong dengan menjadikan lingkungan sebagai media atau bahan ajar. Adanya hubungan antara materi ajar dengan lingkungan dapat pempermudah peserta didik dalam mengingat dan mengerti materi yang diberikan oleh pendidik. Salah satu contoh lingkungan sekitar yang dapat dihubungkan dengan pembelajaran kimia yaitu lahan basah. Menyatupadukan masalah pada lahan basah dengan proses belajar mengajar menunjang bertambahnya pengetahuan kearifan lokal peserta didik.

Proses kimiawi yang terjadi pada lahan basah akibat terjadinya fenomena alam seperti kebakaran lahan gambut, penurunan tingkat kesuburan tanaman pada lahan gambut dan senyawa-senyawa penyusunnya. Penurunan tingkat kesuburan dapat dihubungkan dengan materi kimia, yaitu materi Stoikiometri. Stoikiometri mempelajari tentang hukum dasar kimia, persamaan reaksi kimia dan perhitungan kimia. Reaksi kimiawi pada penyuburan tanah gambut memalui proses pemupukkan dapat dijadikan salah satu objek permasalahan pada materi stoikiometri.

\section{METODE PENELITIAN}

Rancangan ini membandingkan keadaan kelompok yang sama-sama mendapatkan perlakuan. Perlakuan yang diberikan sesuai dengan variabel bebasnya yaitu model pembelajaran. Variabel bebas ini akan berpengaruh pada variabel terikatnya yaitu hasil belajar dan keterampilan proses sains. Penelitian dilaksakan pada bulan Februari sampai Juni 2019 yang bertempat di SMA Negeri 12 Banjarmasin. Peserta didik SMA Negeri 12 adalah populasi dari penelitian ini. Dua kelas diantaranya digunakan sebagai sampel penelitian. Teknik pengumpulan data menggunakan test dan non-test dengan perangkat penelitian berupa RPP, LKPD dan lembar penilaian.

Hasil perhitungan validasi instrumen tes dan non tes memiliki nilai CVR sebesar 1,00. Uji reliabilitas intrumen tes pengetahuan hasil belajar masuk dalam kategori sedang dengan nilai 0,53. Adapun tingkat kesukaran dari intrumen tes yang digunakan terdapat 2 soal kategori sukar, 5 soal kategori sedang, dan 3 soal kategori mudah. Hasil perhitungan daya beda Instrumen tes pengetahuan hasil belajar, terdapat 1 soal kategori baik sekali, 5 soal kategori baik, dan 4 soal kategori cukup.

\section{HASIL PENELITIAN DAN PEMBAHASAN}

\section{Hasil Penelitian}

Rata-rata hasil belajar pengetahuan pada kedelapan indikator materi stoikiometri:

Tabel 1. Rata-rata hasil belajar pengetahuan tiap indikator

\begin{tabular}{cccccc}
\hline \multirow{2}{*}{ No } & \multirow{2}{*}{ Indikator } & \multicolumn{2}{c}{ Pre-test } & \multicolumn{2}{c}{ Post-test } \\
\cline { 3 - 6 } & Eksperimen & Kontrol & Eksperimen & Kontrol \\
\hline \multirow{2}{*}{1} & $\begin{array}{l}\text { Peserta didik dapat } \\
\text { menghitung massa } \\
\text { molekul relatif. }\end{array}$ & 46,47 & 57,14 & 93,33 & 88,57 \\
\hline
\end{tabular}




\begin{tabular}{clcccc}
\hline \multirow{2}{*}{ No } & \multicolumn{1}{c}{ Indikator } & \multicolumn{2}{c}{ Pre-test } & \multicolumn{2}{c}{ Post-test } \\
\cline { 2 - 6 } 2 & $\begin{array}{l}\text { Peserta didik dapat } \\
\text { menentukan rumus } \\
\text { molekul zat dan rumus } \\
\text { empiris. }\end{array}$ & 50,00 & 31,43 & 80,00 & 42,86 \\
\hline & $\begin{array}{l}\text { Peserta didik dapat } \\
\text { menghitung komposisi } \\
\text { setiap unsur pada suatu } \\
\text { senyawa. }\end{array}$ & 36,47 & 8,57 & 70,00 & 74,28 \\
\hline 4 & $\begin{array}{l}\text { Peserta didik dapat } \\
\text { menyimpulkan hasil } \\
\text { reaksi kimia. }\end{array}$ & 0,00 & 11,43 & 86,67 & 62,86 \\
\hline 5 & $\begin{array}{l}\text { Peserta didik dapat } \\
\text { menganalisis hukum- } \\
\text { hukum dasar kimia. }\end{array}$ & 15,00 & 10,00 & 83,34 & 85,71 \\
\hline 6 & $\begin{array}{l}\text { Peserta didik dapat } \\
\text { menghitung mol zat. }\end{array}$ & 10,00 & 31,43 & 83,33 & 82,86 \\
\hline 7 & $\begin{array}{l}\text { Peserta didik dapat } \\
\text { menganalisis massa dan } \\
\text { volume produk. }\end{array}$ & 21,67 & 12,85 & 78,335 & 81,43 \\
\hline 8 & $\begin{array}{l}\text { Peserta didik dapat } \\
\text { menganalisis adanya } \\
\text { reaksi pembatas. }\end{array}$ & 20,00 & 14,28 & 93,33 & 60,00 \\
\hline Rata-rata & 24,95 & 22,14 & 83,54 & 72,32 \\
\hline & & & & \\
\hline
\end{tabular}

Tingkat pemahaman tertinggi ada pada indikator 1. Tingkat pemahaman terendah kelas eksperiman ada pada indikator 3 dan pada kelas kontrol indikator 2 . Berikut hasil tes $N$-gain pengetahuan peserta didik setelah mengikuti pembelajaran materi stoikiometri:

Tabel 2. Interpretasi $N$-gain pengetahuan peserta didik

\begin{tabular}{ccc}
\hline Kelas & Rata-rata $\boldsymbol{N}$-gain & Kategori \\
\hline Eksperimen & 0,79 & Tinggi \\
Kontrol & 0,69 & Sedang \\
\hline
\end{tabular}

Hasil uji normalitas sebagai berikut:

Tabel 3. Hasil uji normalitas data pre-test dan post-test pengetahuan

\begin{tabular}{cccccc}
\hline Hasil & Kelas & $\mathbf{N}$ & $\mathbf{L}_{\mathbf{0}}$ & $\mathbf{L}_{\text {tabel }}$ & Kesimpulan \\
\hline \multirow{2}{*}{ Pre-test } & Eksperimen & 30 & 0,141 & 0,161 & Normal \\
\cline { 2 - 6 } & Kontrol & 35 & 0,141 & 0,150 & Normal \\
\hline \multirow{2}{*}{ Post-test } & Eksperimen & 30 & 0,105 & 0,161 & Normal \\
\cline { 2 - 6 } & Kontrol & 35 & 0,125 & 0,150 & Normal \\
\hline
\end{tabular}

Hasil uji homogenitas kedua kelas tersebut seperti tabel berikut:

Tabel 4. Hasil uji homogenitas pre-test dan post-test pengetahuan

\begin{tabular}{cccccccc}
\hline Hasil & Kelas & $\mathbf{N}$ & $\mathbf{d b}$ & $\mathbf{S D}^{\mathbf{2}}$ & $\mathbf{F}_{\text {hitung }}$ & $\mathbf{F}_{\text {tabel }} \mathbf{5 \%}$ & \multirow{2}{*}{ Kesimpulan } \\
\hline \multirow{2}{*}{ Pre-test } & Eksperimen & 30 & 29 & 126,79 & \multirow{2}{*}{1,76} & \multirow{2}{*}{1,80} & \multirow{2}{*}{ Homogen } \\
\cline { 2 - 5 } Post-test & Kontrol & 35 & 34 & 223,50 & & & \multirow{2}{*}{ Homogen } \\
\cline { 2 - 5 } & Eksperimen & 30 & 29 & 173,45 & \multirow{2}{*}{1,67} & 1,80 & \\
\hline
\end{tabular}


Kemudian dilakukan uji-t:

Tabel 5. Hasil uji-t data pre-test dan post-test pengetahuan

\begin{tabular}{|c|c|c|c|c|c|c|c|}
\hline Hasil & Kelas & Db & $\overline{\mathbf{X}}$ & $D^{2}$ & $\mathbf{t}_{\text {hitung }}$ & $\begin{array}{l}\mathrm{t}_{\text {tabel }} \\
\mathbf{5 \%}\end{array}$ & Kesimpulan \\
\hline \multirow{2}{*}{ Pre-test } & Eksperimen & \multirow{2}{*}{63} & 18,00 & 26,78 & \multirow{2}{*}{0,60} & \multirow{2}{*}{2,00} & \multirow{2}{*}{ Tidak signifikan } \\
\hline & Kontrol & & 20,00 & 23,50 & & & \\
\hline \multirow{2}{*}{$\begin{array}{l}\text { Post- } \\
\text { test }\end{array}$} & Eksperimen & \multirow{2}{*}{63} & 83,00 & 73,45 & \multirow{2}{*}{2,21} & \multirow{2}{*}{2,00} & \multirow{2}{*}{ Signifikan } \\
\hline & Kontrol & & 74,57 & 90,36 & & & \\
\hline
\end{tabular}

Pembelajaran dilakukan sebanyak empat pertemuan, dari pertemuan pertama hingga akhir dilakukan penilaian sikap peserta didik menggunakan lembar observasi dengan hasil sebagai berikut:

Tabel 6. Hasil penilaian sikap peserta didik kelas eksperimen

\begin{tabular}{|c|c|c|c|c|c|c|c|c|}
\hline \multirow[b]{2}{*}{ Aspek yang diamati } & \multicolumn{4}{|c|}{ Rata-rata Kelas Eksperimen } & \multicolumn{4}{|c|}{ Rata-rata Kelas Kontrol } \\
\hline & $\begin{array}{l}\text { P1 } \\
(\%)\end{array}$ & $\begin{array}{c}\text { P2 } \\
(\%)\end{array}$ & $\begin{array}{l}\text { P3 } \\
(\%)\end{array}$ & $\begin{array}{l}\text { P4 } \\
(\%)\end{array}$ & $\begin{array}{l}\text { P1 } \\
(\%)\end{array}$ & $\begin{array}{l}\mathbf{P 2} \\
(\%)\end{array}$ & $\begin{array}{l}\text { P3 } \\
(\%)\end{array}$ & $\begin{array}{l}\text { P4 } \\
(\%)\end{array}$ \\
\hline Rasa ingin tahu & 53,33 & 69,33 & 81,33 & 94,00 & 53,71 & 65,71 & 81,14 & 91,42 \\
\hline Kategori & $\mathrm{CB}$ & $\mathrm{B}$ & $\mathrm{B}$ & $\mathrm{SB}$ & $\mathrm{CB}$ & $\mathrm{CB}$ & $\mathrm{B}$ & $\mathrm{SB}$ \\
\hline Tanggungjawab & 56,67 & 66,67 & 79,00 & 90,00 & 58,86 & 69,14 & 79,43 & 90,85 \\
\hline Kategori & $\mathrm{CB}$ & $\mathrm{CB}$ & $\mathrm{B}$ & SB & $\mathrm{CB}$ & $\mathrm{CB}$ & $\mathrm{B}$ & SB \\
\hline Kerjasama & 61,33 & 72,67 & 87,33 & 94,67 & 61,71 & 72,57 & 86,28 & 92,00 \\
\hline c Kategori & $\mathrm{CB}$ & $\mathrm{B}$ & $\mathrm{SB}$ & SB & $\mathrm{CB}$ & $\mathrm{B}$ & SB & SB \\
\hline Rata-rata & 57,11 & 69,56 & 82,55 & 92,89 & 58,09 & 69,14 & 82,28 & 91,42 \\
\hline Kategori & $\mathrm{CB}$ & B & B & SB & $\mathrm{CB}$ & B & $\mathrm{B}$ & SB \\
\hline \multicolumn{9}{|l|}{ Keterangan: } \\
\hline $\begin{array}{ll}\mathrm{P} & =\text { Pertemuan } \\
\mathrm{B} & =\text { Baik }\end{array}$ & : $S$ & & ukup & & & & & \\
\hline
\end{tabular}

Tabel 7. Hasil penilaian keterampilan proses sains peserta didik kelas eksperimen

\begin{tabular}{|c|c|c|c|c|c|c|c|c|}
\hline \multirow[b]{2}{*}{ Aspek yang diamati } & \multicolumn{4}{|c|}{ Rata-rata Kelas Eksperimen } & \multicolumn{4}{|c|}{ Rata-rata Kelas Kontrol } \\
\hline & $\begin{array}{l}\text { P1 } \\
(\%)\end{array}$ & $\begin{array}{l}\text { P2 } \\
(\%)\end{array}$ & $\begin{array}{l}\mathbf{P 3} \\
(\%)\end{array}$ & $\begin{array}{l}\text { P4 } \\
(\%)\end{array}$ & $\begin{array}{l}\text { P1 } \\
(\%)\end{array}$ & $\begin{array}{l}\text { P2 } \\
(\%)\end{array}$ & $\begin{array}{l}\mathbf{P 3} \\
(\%)\end{array}$ & $\begin{array}{l}\text { P4 } \\
(\%)\end{array}$ \\
\hline Mengamati & 50,00 & 59,33 & 66,00 & 72,00 & 47,43 & 55,43 & 59,43 & 63,43 \\
\hline Kategori & KT & $\mathrm{CT}$ & $\mathrm{CT}$ & $\mathrm{T}$ & KT & $\mathrm{CT}$ & $\mathrm{CT}$ & $\mathrm{CT}$ \\
\hline Mengklasifikasi & 52,00 & 59,33 & 66,67 & 72,67 & 54,86 & 59,43 & 62,28 & 64,57 \\
\hline Kategori & $\mathrm{CT}$ & $\mathrm{CT}$ & $\mathrm{CT}$ & $\mathrm{T}$ & $\mathrm{CT}$ & $\mathrm{CT}$ & $\mathrm{CT}$ & $\mathrm{CT}$ \\
\hline Memprediksi & 54,67 & 62,00 & 66,00 & 72,67 & 54,86 & 60,00 & 65,14 & 66,28 \\
\hline Kategori & $\mathrm{CT}$ & $\mathrm{CT}$ & $\mathrm{CT}$ & $\mathrm{T}$ & CT & $\mathrm{CT}$ & $\mathrm{CT}$ & $\mathrm{T}$ \\
\hline Menyimpulkan & 52,67 & 60,00 & 64,67 & 71,33 & 54,86 & 59,43 & 65,71 & 68,57 \\
\hline Kategori & $\mathrm{CT}$ & $\mathrm{CT}$ & $\mathrm{CT}$ & $\mathrm{T}$ & CT & $\mathrm{CT}$ & $\mathrm{CT}$ & $\mathrm{T}$ \\
\hline $\begin{array}{ll}\text { Mengkomunikasi- } \\
\text { e } \\
\text { kan }\end{array}$ & 56,67 & 62,00 & 70,00 & 78,00 & 55,43 & 60,57 & 66,86 & 72,57 \\
\hline Kategori & $\mathrm{CT}$ & $\mathrm{CT}$ & $\mathrm{T}$ & $\mathrm{T}$ & $\mathrm{CT}$ & CT & CT & $\mathrm{T}$ \\
\hline Rata-rata & 53,20 & 60,53 & 66,67 & 73,33 & 53,48 & 58,97 & 63,88 & 67,08 \\
\hline Kategori & $\mathrm{CT}$ & $\mathrm{CT}$ & $\mathrm{CT}$ & $\mathrm{T}$ & $\mathrm{CT}$ & $\mathrm{CT}$ & $\mathrm{CT}$ & $\mathrm{CT}$ \\
\hline
\end{tabular}

Keterangan:

\begin{tabular}{|c|c|c|c|}
\hline CK & $\begin{array}{l}=\text { Pertemuan } \\
=\text { Cukup Terampil }\end{array}$ & & $\begin{array}{l}=\text { Kurang Terampil } \\
=\text { Teramnil }\end{array}$ \\
\hline
\end{tabular}


Berikut rata-rata respon peserta didik:

Tabel 8. Rata-rata nilai respon peserta didik

\begin{tabular}{ccc}
\hline Kelas & Nilai rata-rata & Kriteria \\
\hline Eksperimen & 40,43 & Baik \\
\hline Kontrol & 38,80 & Baik \\
\hline
\end{tabular}

\section{Pembahasan}

Problem based learning mempunyai beberapa kelebihan salah satunya menjadikan masalah dikehidupan nyata sebagai pemicu proses pembelajaran. Menurut Adityas \& Saadi, (2015) model pembelajaran ini berorientasi pada proses dan penekanan keterlibatan peserta didik untuk memecahkan masalah yang dikonstruksi dalam bentuk pertanyaan memalui kerja kelompok. Keunggulan lain dari problem based learning adalah pembelajaran menjadi lebih menyenangkan dan disukai dibandingkan pembelajaran konvensional yang biasa diterapkan. Hal ini diungkapkan oleh Redhana, (2013) bahwa peserta didik memberikan pendapat sangat setuju dengan diterapkannya model problem based learning.

Pre-test dan post-test dilakukan untuk mengetahui rata-rata hasil pengetahuan. Menurut hasil uji homogenitas, kemampuan awal kedua kelas tersebut homogen. Nilai pre-test kedua kelas sebelum diberi perlakuan berupa proses pembelajaran, menurut perhitungan statistik tidak terjadi perbedaan yang signifikan. Setelah diberi perlakuan berupa proses pembelajaran hasilnya sebagai berikut:

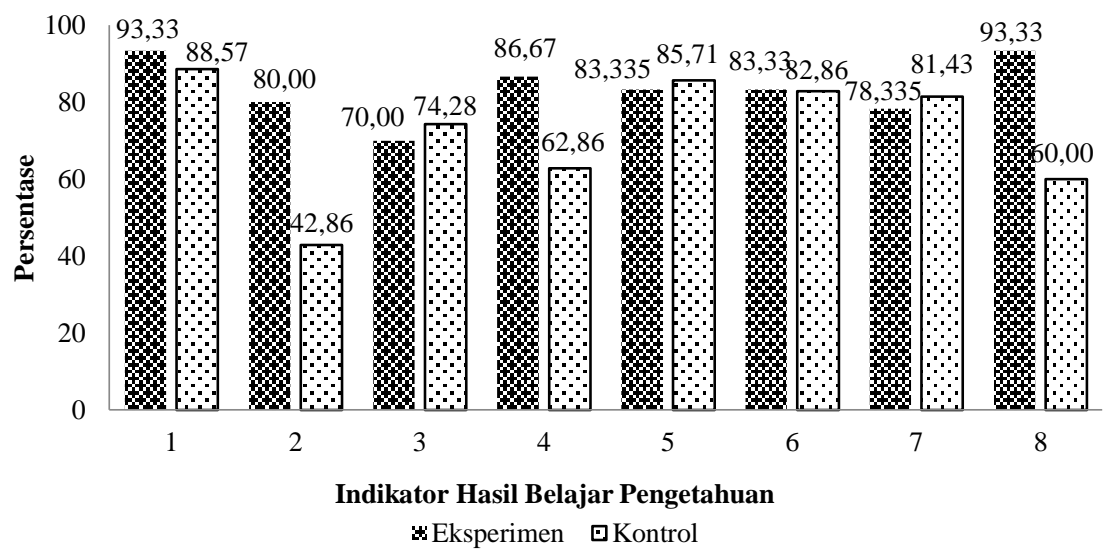

Gambar 1. Nilai rata-rata pengetahuan post-test peserta didik pada setiap indikator Keterangan Indikator:

$1=$ menghitung massa molekul relatif

$2=$ menentukan rumus molekul zat dan rumus empiris

$3=$ menghitung komposisi setiap unsur pada suatu senyawa

$4=$ menyimpulkan hasil reaksi kimia

$5=$ menganalisis hukum-hukum dasar kimia

$6=$ menghitung mol zat

$7=$ menganalisis massa dan volume produk

$8=$ menganalisis adanya reaksi pembatas

Penelitian yang dilakukan menggunakan 8 indikator, 3 diantaranya hasil belajar kelas kontrol lebih unggul daripada kelas eksperimen. Indikator tersebut adalah indikator 3, 5, dan 7. Hal ini disebabkan pendidik yang menerapkan modelmodel pembelajaran pada kedua kelas tersebut merupakan pendidik yang masih 
dalam tahap pendidikan (Mahasiswa) sehingga hasilnya kurang optimal. Namun secara keseluruhan sudah terjadi pebedaan yang signifikan bedasarkan uji-t yang telah dilakukan.

Nilai $\mathrm{N}$-gain menyatakan perbedaan peningkatan pengetahuan kelas eksperimen dengan kontrol. Perhitungan ini selaras dengan penelitian Arfianawati, (2016) yang menunjukkan angka hasil belajar kelas yang menerapkan model pembelajaran kimia berbantuan LKPD etnosains lebih tinggi dibandingkan dengan pembelajaran konvensional. Pembelajaran sains yang melibatkan peserta didik untuk melakukan penemuannya sendiri dan menghubungkannya dengan konsep kehidupan nyata memberikan pengalaman belajar yang lebih bermakna dan akan tertanam kuat di pikiran peserta didik (Fitriani, Widiyatmoko, \& Khusniati, 2016).

Hasil yang diperoleh juga tidak berbeda jauh dengan penelitian yang dilakukan Puspita, (2014) menyatakan adanya interaksi positif hasil belajar pengetahuan dengan model problem based learning. Pernyataan ini diperkuat oleh hasil peneliatian Wahyudi, (2015) bahwa hasil belajar sikap peserta didik yang menerapkan problem based learning berhasil mencapai rata-rata $76,09 \%$. Selanjutnya hasil belajar sikap pada empat pertemuan ini dirangkum dalam diagram berikut:

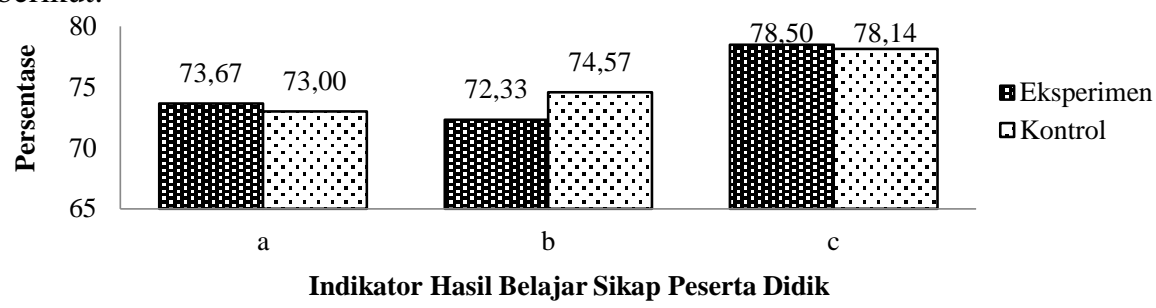

Gambar 2. Hasil observasi sikap peserta didik pada setiap indikator

Keterangan:

$\mathrm{a}=$ Rasa ingin tahu

$\mathrm{b}=$ Tanggungjawab

$\mathrm{c}=$ Kerjasama

Penggunaan materi lahan basah dapat meningkatkan sikap yang dimiliki peserta didik khususnya pada aspek rasa ingin tahu. Pendidik berperan penting dalam kegiatan belajar guna menimbulkan rasa ingin tahu, dan meminimalkan resiko kegagalan belajar, sehingga kegiatan pembelajaran relevan dengan kebutuhan peserta didik papar Hariyanto \& Suyono, (2015). Pendidik akan mendorong peserta didik untuk mengajukan hipotesis. Hal ini menyebabkan rasa ingin tahu peserta didik tertantang untuk membuktikan hipotesis yang dibuat (Hosnan, 2016). Selain rasa ingin tahu, model pembelajaran ini juga melatih peserta didik bekerjasama dalam kelompok sebagaimana yang dinyatakan oleh Johnson \& Johnson, (2012) bahwa kerjasama dalam kelompok yang dibangun secara kooperatif dapat menyelesaikan masalah dalam kehidupan sehari-hari.

Menurut Mungzilina, Kristin, \& Anugraheni, (2018) tanggungjawab peserta didik meningkat dari kondisi awal $0 \%$ pada kategori sangat baik menjadi 39,5\% pada kategori bertanggungjawab. Berdasarkan hasil penelitian tersebut maka hasil belajar diperoleh melalui proses pembelajaran dengan tujuan adanya perubahan tingkah laku. Hasil ini sebanding dengan Murni, (2016) yang memaparkan penerapan problem based learning mampu menambah sikap tanggungjawab peserta. Aspek lainnya yang meningkat adalah kerja sama, hasil penelitian yang serupa juga diungkapkan oleh Lestari, Nurmilawati, \& Santoso, (2015) yakni meningkatnya 
sikap sosial peserta didik disebabkan oleh penerapan model pembelajaran berbasis masalah dapat. Perbandingan hasil observasi keterampilan proses sains dapat dilihat pada diagram berikut:

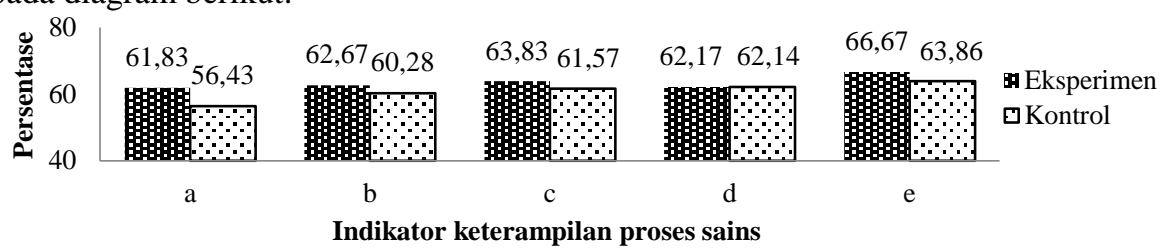

Gambar 3. Hasil observasi keterampilan proses sains peserta didik pada setiap

Keterangan:

$\mathrm{a}=$ Mengamati

$\mathrm{b}=$ Mengklasifikasi

$\mathrm{c}=$ Memprediksi

$\mathrm{d}=$ Menyimpulkan

$\mathrm{e}=$ Mengkomunikasikan

Berdasarkan gambar 3 kelas eksperimen lebih terampil daripada kelas kontrol dan menunjukkan adanya perbedaan pada kedua kelas. Hartini, Kusasi, \& Iriani, (2017) juga memperoleh peningkatan keterampilan proses sains dari kategori cukup terampil menjadi terampil.

Rata-rata setiap pertemuan menunjukkan kenaikan sehingga dapat dikatakan bahwa model pembelajaran bermbasis masalah yang dihubungkan dengan lahan basah efektif digunakan dalam pembelajaran kimia materi stoikiometri. Hal ini selaras dengan penelitian Wirda, Gani, Khaldun (2015) yang menyatakan nilai $N$ gain kelas eksperimen lebih terampil daripada nilai $\mathrm{N}$-gain kelas kontrol. Penelitian Ariani, Hamid, \& Leny, (2015) juga menyatakan naiknya keterampilan proses sains dari setiap aspek yang diukur yang ditandai dengan kemampuan peserta didik dalam memperluas keterampilan proses sainsnya. Analisis respon peserta didik terhadap pernyataan-pertanyaan yang diajukan dapat dilihat pada diagram berikut:

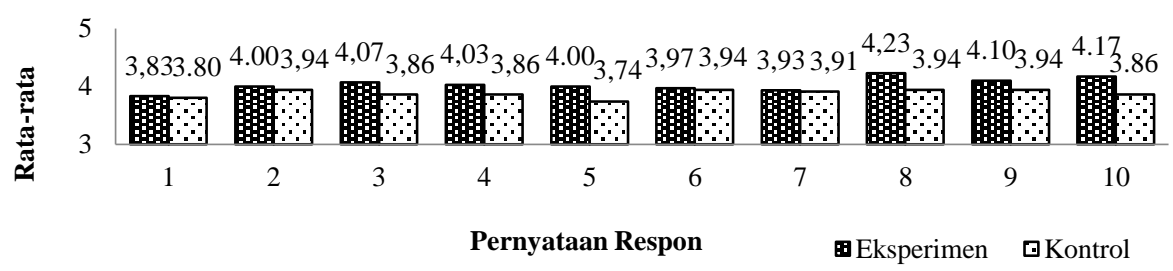

Keterangan:

Pernyataan 1: $\quad$ Model yang diterapkan pada materi stoikiometri menarik sehingga saya senang untuk mengikuti pelajaran tersebut

Pernyataan 2: $\quad$ Model yang diterapkan pada materi stoikiometri dapat membuat saya berpartisipasi secara aktif dalam belajar

Pernyataan 3: Penerapan menggunakan model pembelajaran ini membuat saya terlibat langsung dalam proses pembelajaran

Pernyataan 4: Pembelajaran menggunakan model pembelajaran ini membuat saya berani bertanya dan mengungkapkan pendapat

Pernyataan 5: Saya merasa kegiatan pembelajaran dengan penerapan model ini kemampuan berpikir kreatif saya menjadi berkembang

Pernyataan 6: Pembelajaran dengan kegiatan diskusi kelompok pada model ini memberikan saya banyak pengalaman

Pernyataan 7: $\quad$ Kegiatan diskusi memudahkan saya untuk memecahkan permasalahan 


$\begin{array}{ll} & \text { yang diberikan oleh pendidik } \\ \text { Pernyataan 8: } & \begin{array}{l}\text { Penerapan model pembelajaran ini membuat saya bebas mengeluarkan } \\ \text { ide-ide menarik dan kreatif untuk menyelesaikan masalah }\end{array} \\ \text { Pernyataan 9: } & \begin{array}{l}\text { Saya merasa termotivasi untuk mengikuti pelajaran dengan baik untuk } \\ \text { materi stoikiometri dengan model pembelajaran ini }\end{array} \\ \text { Pernyataan 10: } & \begin{array}{l}\text { Pembelajaran menggunakan model ini cocok digunakan dalam } \\ \text { stoikiometri }\end{array}\end{array}$

Berdasarkan gambar 4 respon lebih baik diberikan oleh peserta didik kelas eksperimen. Penggunaan pembelajaran berkonteks lahan basah menjadi hal baru yang didapatkan selama pembelajaran kimia. Hasil penelitian ini selaras dengan penelitian Ekapti, (2016) dimana respon peserta didik kelas eksperimen lebih baik daripada kelas kontrol. Penelitian Atmojo, (2012) juga sejalan dimana apresiasi peserta didik mengalami peningkatan pada pembelajaran IPA berpendekatan etnosains terhadap profesi pengrajin tempe di daerah Kedungtuban. Pembelajaran juga menjadi lebih menarik bagi peserta didik disebabkan fakta yang didukung dalam metode pembelajaran untuk mengaitkan pengetahuan ataupun pengalaman yang dimiliki peserta didik (Nargundkar, Samaddar, \& Mukhopadhyay, 2014).

\section{SIMPULAN}

Terdapat perbedaan keterampilan proses sains dan hasil belajar yang signifikan antara pembelajaran yang menggunakan model pembelajaran problem based learning berkonteks lahan basah dan model pembelajaran konvensional (ekspositori) pada materi stoikiometri.

\section{DAFTAR RUJUKAN}

Adityas, A. O., \& Saadi, P. (2016). Pengaruh Model Problem Based Learning (PBL) Berbasis Aktivitas Metakognisi Terhadap Kemampuan Memecahkan Masalah Kelarutan dan Hasil Kali Kelarutan pada Siswa Kelas XI SMA Negeri 2 Banjarmasin. Quantum: Jurnal Inovasi Pendidikan Sains, 6(2).

Agusfianor, R., Istyadji, M., \& Saadi, P. (2017). Kajian Keberlanjutan Pemahaman Konsep Siswa pada Materi larutan elektrolit dan redoks Kelas X MIA 3 SMA Negeri 5 Banjarmasin Tahun Ajaran 2016/2017. Journal Of Chemistry And Education (JCAE), 1(1), 111-118.

Arends, R. I. (2008). Belajar untuk Mengajar Edisi Ketujuh. Terj. Soetjipto HP Yogyakarta: Pustaka Pelajar.(Buku Asli diterbitkan 2007).

Arfianawati, S., Sudarmin, M., \& Sumarni, W. (2016). Model Pembelajaran Kimia Berbasis Etnosains untuk Meningkatkan Kemampuan Berpikir Kritis Siswa. Jurnal Pengajaran MIPA, 21(1), 46-51.

Ariani, M., Hamid, A., \& Leny, L. (2017). Meningkatkan Keterampilan Proses Sains dan Hasil Belajar Siswa pada Materi Koloid dengan Model Inkuiri Terbimbing (Guided Inquiry) pada Siswa Kelas XI IPA 1 SMA Negeri 11 Banjarmasin. Quantum: Jurnal Inovasi Pendidikan Sains, 6(1), 98-107.

Atmojo, S. E. (2012). Profil Keterampilan Proses Sains dan Apresiasi Siswa terhadap Profesi Pengrajin Tempe dalam Pembelajaran IPA Berpendekatan Etnosains. Jurnal Pendidikan IPA Indonesia, 1(2), 34-40.

Ekapti, R. F. (2016). Respon Siswa dan Guru dalam Pembelajaran IPA Terpadu Konsep Tekanan Melalui Problem Based Learning. Jurnal Pena Sains, 3(2), 109-115.

Fitriani, N. R., Widiyatmoko, A., \& Khusniati, M. (2016). The Effectiveness of Ctl Model Guided Inquiri-based in the Topic of Chemicals in Daily Life to Improve Students' Learning Outcomes and Activeness. Jurnal Pendidikan 
IPA Indonesia, 5(2), 278-283.

Hariyanto, \& Suyono. (2015). Belajar dan Pembelajaran: Teori dan Konsep Dasar. Bandung: Remaja Rosdakarya

Hartini, E. M., Kusasi, M., \& Iriani, R. (2017). Meningkatkan Keterampilan Proses Sains dan Hasil Belajar Melalui Model Problem Solving dengan Pendekatan Saintifik pada Materi Hidrolisis Garam. Journal Of Chemistry And Education (JCAE), 1(1), 37-45.

Hosnan, M. (2016). Pendekatan Saintifik dan Kontekstual Dalam Pembelajaran Abad 21 Kunci Sukses Implementasi Kurikulum 2013. Bogor: Ghalia Indonesia.

Johnson, D. W., \& Johnson, F. P. (2012). Dinamika Kelompok dan Keterampilan. Jakarta: Indeks.

Khairunnisa, K., Saadi, P., \& Leny, L. (2017). Pengembangan Media Pembelajaran "Buku Teka-Teki Kimia" untuk Kelas XI SMA. Journal Of Chemistry And Education (JCAE), 1(1), 151-155.

Lestari, Nurmilawati, \& Santoso. (2015). Penerapan Problem Based Learning (Pbl) Untuk Meningkatkan Kemampuan Berpikir Kritis Dan Sikap Sosial Peserta Didik Kelas ViiI. Prosiding Seminar Nasional Pendidikan Biologi 2015 $U N M, 465-471$.

Mungzilina, A. K., Kristin, F., \& Anugraheni, I. (2018). Penerapan model pebelajaran problem based learning untuk meningkatkan tanggungjawab dan hasil belajar siswa kelas 2 SD. Jurnal Kajian Penelitian Pendidikan dan Pembelajaran , 184-195.

Murni, S. (2016). Meningkatkan Hasil Belajar IPA, Sikap Tanggung Jawab dan Kerjasama Melalui Model Problem Based Learning. Basic Education, 5(29), 2-781.

Nargundkar, S., Samaddar, S., \& Mukhopadhyay, S. (2014). A Guided ProblemBased Learning (PBL) Approach: Impact on Critical Thinking. Decision Sciences Journal of Innovative Education, 12(2), 91-108.

Puspita, L. S. (2014). Pengaruh Model Problem Based Learning Dengan Metode Eksperimen Disertai Teknik Concept Map Dan Mind Map Terhadap Prestasi Belajar Biologi Ditinjau Dari Motivasi Belajar Dan Aktivitas Belajar Siswa. Jurnal Inkuiri , 85-89.

Redhana, I. W. (2013). Model Pembelajaran Berbasis Masalah untuk Peningkatan Keterampilan Pemecahan Masalah dan Berpikir Kritis. Jurnal Pendidikan dan Pengajaran, 46(1), 78-86.

Wahyudi, A. (2015). Pengaruh Problem Based Learning terhadap Keterampilan Proses Sains dan Hasil Belajar Biologi Siswa Kelas X SMA Negeri Jumapolo Tahun Pelajaran 2013/2014. Bio-Pedagogi, 4(1), 5-11.

Wirda, W., Gani, A., \& Khaldun, I. (2015). Penerapan Pembelajaran Model Problem Based Learning (Pbl) Untuk Meningkatkan Keterampilan Proses Sains Dan Motivasi Belajar Siswa Pada Materi Alat-alat Optik. Jurnal Pendidikan Sains Indonesia (Indonesian Journal of Science Education), 3(2), 131-142. 